\title{
Tacit Knowledge and In-service Training of Civil Servants
}

\author{
UDK: $331.103: 374: 352$

\section{Roman Lavtar} \\ Government of the Republic Slovenia, \\ Office for Local Self-Government and Regional Policy \\ University of Ljubljana, Faculty of Administration \\ roman.lavtar@gov.si
}

\begin{abstract}
The main purpose of the paper is to evaluate possibilities provided by organizational knowledge creation theory (Nonaka, 1994) for seeking after knowledge of civil servants. The fundamental task of organization (both, public or private, profit or non-profit) is how efficiently it can deal with information and decisions in an uncertain environment. Information processing is viewed as a problem-solving activity. But innovation, the key form of organizational knowledge creation, cannot be explained in terms of information processing or problem solving but with the process where organization is developing new knowledge to solve problems (Nonaka, 1994: 15). Due to the recent decision of Slovene government to abort the state exam for civil servants we elaborate the question of necessity of the pre-service and in-service training of civil servants and in what manner that training should be performed. Elaborating some experience in the neighborhood countries we try to find some conclusions of the topic. On the other hand we explore the possibilities given by organizational knowledge creation theory in in-service training of civil servants and its implications on choosing the topics of the training.
\end{abstract}

Key words: pre-service training, in-service training, knowledge, organizational knowledge, organizational knowledge creation theory.

\section{Introduction}

One of the most important aspects of stateness is relevant institutional capacity, importantly linked to organizational design and management of the society. It's public administration incorporates significant capacity of high transferable knowledge (Fukuyama, 2004: 31). It enables development of democratic values and economic prosperity. This is one of the reasons why international organizations like OECD or EU hold high standards of public administration capacity to create new knowledge for solving everyday problems. The 


\section{Roman Lavtar}

\section{Tacit Knowledge and In-service Training of Civil Servants}

question is how to keep civil servants in condition to fulfill to demands of future development. There is no optimal form of organization in private and in public sector, no globally valid rules for organizational design. So the field of public administration is necessarily more of an art than a science and most good solution problems will not be successful in another environment because it will have to incorporate a great deal of context-specific information (Fukuyama, 2004: 43). Here we come to the important distinction between data, information and knowledge. Data can be defined as raw number, images, words and sounds which are derived from our observation or measurement. Information represents data arranged in a meaningful pattern, data enriched with some intellectual input. And knowledge can be understood to emerge from the application, analysis and productive use of data and information (Hislop, 2005: 15, Davenport and Prusak, 1997: 6). Civil servants and especially their managers must be able to make a distinction between those because they otherwise miss to get proper ideas for finding adequate solutions.

In uncertain circumstances and in situation in which organizations are trying to get the competitive advantage or in case of public organizations to fulfill the expectations of public, with interacting and sharing knowledge among employees, organizations are enhancing the capacity to define a situation or solve a problem (Nonaka, 1994: 14). Organizational knowledge creation theory's contribution to organizational behavior is crucial for discovering two types of knowledge: tacit (informal, hidden and hard to codify) and explicit (formal, easy to codify). In organizations according to the theory knowledge expands through a four-stage conversion process (SECl model: socialization aims at sharing tacit knowledge among individuals, externalization aims at articulating tacit knowledge into explicit, combination aims at combining different entities of explicit knowledge and internalization aims at embodying explicit knowledge into tacit knowledge).

How can we benefit from organizational knowledge creation theory in inservice training of civil servants? It looks like we need to change radically traditional approaches to the problem especially to training of senior civil servants on managerial positions. It is not only important to decide on organization form of in-service training between supplier funded and buyer funded model (Civil service training ... 2003: 10) but on substance of training as well. More or less centralized organizational structure of civil servants' in-service training indeed depends on specific circumstances in given country. Centralized personnel management systems are generally more cost-effective than decentralized 
systems (Schiavo-Campo, OECD, 1996: 13), but best value for money is not the only criteria in this case. The decision on organization of civil servants training also corresponds to broader environment (system of pre-service education of future candidates etc.). But this has nothing to do with content of the training which can be in any organizational form of training the same. In our paper we will try to elaborate possible changes of in-service civil training regarding to advantages given to organizations by sharing knowledge in knowledge intensive organizations (Hislop, 2005: 215). We will explore possible motivations, willingness and obstacles for sharing knowledge and search for educational approaches in in-service training which will provide better environment for knowledge sharing processes and building team work (Drew and CoulsonThomas, 1996).

\section{Necessity of In-Service Training}

As Peter Drucker stated in 1968 we live in a knowledge society. The increasing importance of knowledge in contemporary society calls for a shift of our thinking. This fact has its impact not only on business organizations but also on public sector. We hear more and more about good governance, state capacity, capacity building of public sector and institutional quality. It is a conventional wisdom that institutions are the critical variable in development (Fukuyama, 2004: 22). Good state and local institutions are those who transparently and efficiently serve the needs of citizens. And those institutions need capable and educated civil servants.

Civil servants in state and local administration are facing stagnant or even decreasing revenues. On the other hand citizens are demanding a higher quality of services. The crucial issue is how to allocate the limited budget resources to substantive programmes and staffing in order to ensure the most efficient and effective use of resources. It is rather typical than exception that governments are decreasing staffing and intensify the workload of remaining civil servants. They are forced to do more with less: to reduce overall public expenditure they don't employ new civil servants and they open new projects at the same time. As we can read in some papers of OECD (Support ..., 1997: 4) several countries make use of staff ceilings, either global or specific to each body. The overall number of personnel can be limited as well as the number of personnel in each grade and the staff ratio for different categories. Other countries have introduced strict limits on personnel expenditure. And most of them 


\section{Roman Lavtar}

\section{Tacit Knowledge and In-service Training of Civil Servants}

are closely monitoring the necessity of recruitment. In United Kingdom even they implemented a financial management reform programme that emphasizes close current costs to the individual public body. The various approaches to limiting personnel costs have its advantages and disadvantages especially in conditions where in-service training is affected.

Modern public service legislation and practices incorporating Human Resource Management contribute to preserving institutional memory, continuity, probity and merit, maintaining integrity in public decision-making and public trust in government. According to OECD documents (Building blocks ..., 2007: 11) institutional arrangements contribute to striking balance between supporting "new" values such as performance, efficiency and diversity and preserving "traditional" values like impartiality and legality. There is value-added in collecting experiences from public governance activities into an overall framework of guiding elements which could serve as a benchmark for civil service policy dialogue. In this case we attain public service staff which strives for delivering quality goods and services at minimum costs in organizations with clear objectives and appropriate autonomy and authority. Well trained staff performs their duties and tasks better, is motivated for getting additional knowledge and is able to make decisions when appropriate and necessary. Flat hierarchy in organization gives civil servants more opportunities to participate in decision making process. That makes them satisfied and motivated. So called esprit de corps of civil servants strengthen.

When it comes to the training systems we generally divide them into preservice and in-service training. In pre-service education generally exist two models. First one, sometimes described also as an elite approach (Country profiles ..., 1997: 17), is the prime example executed in France by Ecole Nationale d'Administration. The training goals are focused on educating a small but highly skilled administrative leadership securing a high rate of intra administrative mobility and an inclusive approach to state administration. The disadvantage of this approach is that it is only senior civil servants orientation which causes problem on comprehensive and diligent implementation of competent formulated policy. Modern administration needs well trained all civil servants not only seniors. In other countries like UK and Slovenia pay relatively little regard to pre-service training. They execute no such elitist approach and civil servants are recruited from all kind of higher education schools. The institutions of government and administration are drawing on a much wider pool of potential employees without pre-conditional specific administrative expertise. 
As far as the in-service training is in question there are also different approaches of state funded civil service training. According to the UNDP they are two: supplier funded and buyer funded model and combination of both (Civil service training ..., 2003: 10). In the supplier funded model the training organization is funded by the state budget directly. It invites participants from administrative units with no charge of fees. The model is simple, transparent, centrally planned within state budget and free of charge for the end user namely civil servant. The disadvantage of the model is that it is supply led and insensitive to the real needs of trainees - the training institution is shaping the courses based on its own internal capacity rather than real need of administration. Buyer funded model provides ministry or other administrative unit the opportunity to buy training by their need and from both state funded and private sector training suppliers. In this case the buyer is more sensitive to the real needs of employees and the quantity as much as the quality of training. The disadvantage of this model can be the vulnerability of budget and arbitrary behavior of management of administrative unit in the sense how much money will be spent on training and who will participate in it. In either model the training organization may not deliver courses itself but contract outside institutions and trainers to do so. In the mixed model (Slovenia for example) the training coordinating institution receives the budget (supplier funded model) but there is an allocation of budget to the ministries too so they can express some sensitivity to the demands of the buyers (buyer funded model). Beside Institute for Public Administration (Upravna akademija) under Ministry of Public Administration which plays a role of a training coordinating institution there are several public and private providers of civil servants training in Slovenia. Besides there is certain number of professional (scientific) conventions of lawyers, sociologists, political scientists, economists, specialists in public administration etc. organizing annual conventions which offer civil servants specialized information on new legislation and other trends.

Very often states provide in the framework of the civil service career system proficiency examination for civil servants. To ensure impartiality and competence and to prevent corruption competitive examination of civil servants is the instrument generally used for the entry and promotion in civil service. Originally, this is seen as the best guarantee for a system based on merit and equal opportunity. General civil servants examination has its origins in China which introduced imperial exams in sixth century. Based on that experience and their own practice in India in 1806 the British East India Company established a college near London for training administrators based on the recommendation 
of officials who had seen the Chinese examination system. The civil service based on examination similar to the Chinese system was advocated by a number of Englishmen over the next several decades. A permanent, unified and politically neutral civil service, in which appointments were made on merit, was introduced on the recommendations of the Northcote-Trevelyan report of 1854. In the mid-17th century, Prussia instituted a civil service on a competitive basis. Similar reforms followed in France, where they became the basis for the Napoleonic reforms at the beginning of the 19th century. In the United States, the first Civil Service Commission was established by Congress in 1871, but it only lasted a few years. In 1883 Pendleton Act reestablished a federal Civil Service Commission, and this one lasted. Today a vast majority of modern states practice general examination system, among others in Europe UK, France, Germany, Ireland, Greece, Spain, Turkey, Hungary, Croatia, Slovenia, Albania, Macedonia, in America United States and Brazil and in Asia China, India, Taiwan, Philippines, Japan and Korea.

\section{Tacit Knowledge in Knowledge Organizations}

One of the most important processes in organizations is sharing knowledge. The term "learning organization" is today wide spread in economy but it can be applied to nonprofit organizations as well (Dimovski, Penger and Žnidaršič, 2004). Transformations in organizations in last decades transformed both the character of the work activities people undertake as well as the nature of organizations. Key to transformations has been growing importance of knowledge workers and knowledge-intensive firms (Hislop, 2005: 215). Knowledge worker is somebody whose work is primarily intellectual, creative, non-routine and which involves both the extensive use and creation of knowledge. This definition most definitely describes civil servants as well since most of them are performing a high level of creativity in their work, extensive use of intellectual skills and use theoretical rather than contextual knowledge. But on the other hand Hislop establishes that people are not always motivated and willing to share their knowledge with their co-workers. Even new technologies like ICT do not question that statement. It even comes to tensions between workers and organization. One of the fundamental aims of taylorism was to dispossess craft workers of their knowledge and embody it into explicit managerial principles. What's important for our discussion is the assumption that knowledge was to be divorced from those carrying out work. In addition it was 
proved that knowledge is embedded in practice, embodied in people, socially constructed, culturally embedded and contestable (Hislop, 2005: 29).

Since 1995 Nonaka and Takeuchi presented their discoveries on different concept of knowledge, it is obvious that knowledge has two faces, explicit and tacit. This had an enormous impact on researchers who researched behavior of people inside organizations. Suddenly the whole concept of communication inside organization changed while extracting knowledge from employees was obviously not possible any more. Basically the organizational knowledge creation theory as it is called finds that every person possesses two types of knowledge: tacit which is informal, hidden, nontransferable and hard to codify and explicit which is formal, transferable and easy to codify. Tacit and explicit knowledge are inseparable, "explicit knowledge". In organizations according to the theory knowledge expands through a four-stage conversion process. The so called $\mathrm{SECl}$ model consists of socialization, externalization, combination and internalization: socialization is sharing tacit knowledge among individuals, externalization is articulating tacit knowledge into explicit, combination is combining different entities of explicit knowledge and internalization is embodying explicit knowledge into tacit knowledge. The important consequence of those findings is that idea that all knowledge can be collected in central location in organization proved to be wrong. This can not be achieved even with today's technologies. One can do that with data and to some extent with information but not with knowledge.

So how can we then share the knowledge in organization? Managers or senior civil servants can only be organizers and interpreters of information and knowledge but their most important task is to organize work in organization in a way that knowledge especially tacit one can be shared among employees (Mintzberg, 1994: 13). They have to shift away from hierarchical, bureaucratic structures towards more flexible structures. Employees should be more flexible in hours they work and tasks they do with more internal promotion opportunities. It has been known since 1959 that salary is not the motivator factor but only hygiene one (Herzberg, Mausner and Snyderman, 1959). When hygiene factors once have been satisfied or provided to a level which employees considers acceptable, there will be no dissatisfaction, but neither will be significant positive attitude. And here motivator factors such as achievement, recognition, responsibility, promotion become important. It is also important that inter group or interpersonal conflicts are prevented or managed properly, that people can participate in decision making process and inter personal trust, 


\section{Roman Lavtar}

\section{Tacit Knowledge and In-service Training of Civil Servants}

general organizational culture, HRM practices and attitudes and values of senior level of organizational hierarchy. One of Brazilian entrepreneurs wrote that if organization wants to be successful it has to eliminate Frederick Winslow Taylor's segmentation and specialization of work (Semler, 1989: 83).

All the results of researchers described previously lead us to the conclusion that in-service training of civil servants should be observed not only in sense of organizational structure or form but also redefined in sense of the context itself. The later is most important from the point of view of sharing knowledge in organization. Civil servants should not only be in-service trained and should not only be generally examined but should also be taught about importance of sharing knowledge. They should be for example aware of the importance of teamwork that differs from "group work". In conditions when the pace of change is increasing daily the teamwork is one of very significant methods which compete with speed and technology (Drew and Coulson Thomas, 1996: 7). Benefits of teamwork include breaking down boundaries to effective communication and collaboration, increasing the speed of action, raising the level of commitment, creating a more customer-focused culture and increasing organizational adaptability and flexibility. If we want our workers to act like adults we have to stop treating them like adolescents (Semler, 1989: 79). Most often detected barriers to teamwork are lack of sufficient senior management support and commitment, lack of clear vision, goals and objectives, insufficient release time from other duties for team members, failure to recognize and reward group efforts, inadequate training and skills development, unwillingness to allow teams necessary autonomy and decision making powers, lack of project management skills, political meddling and power politics, lack of team spirit and executive impatience and push for short term results. In addition, significant tool for better flow of tacit knowledge through organization is well informed management e.i. senior civil servants. Arrangements to inform each other and to be informed from above are several. Both formal and informal have equal impact on good managerial performance (Preston, 1986: 526). The need to know has to be implanted in every day attitude of civil servants and their leaders, interaction must be a source of meaning and joint action that enables them to define current situation and react. To be involved in an arrangement to inform, a manager had to be defined by the others as a reliable and accurate informant. We need to be aware of the fact that informal sources for informing are constructed and used because of limitations or impediments in the formal information system. Use of ICT gives us the wrong impression that we are informed. 


\section{Roman Lavtar \\ Tacit Knowledge and In-service Training of Civil Servants}

\section{Conclusions}

General civil servants examination is the top of the iceberg of civil servants in-service training. It is the beginning of a voyage of employees in public sector. But what counts is in-service training that comes after jumping into the water. It appears that we haven't used all the possibilities offered by late findings about importance of sharing tacit knowledge in organizations. The present paper tries to reflect some possible applications of those acknowledgments and offers incentives for further investigation and new practice. Hopefully we have well developed awareness of importance of permanent reform in public sector including system of training of employees. Fill rouge of our efforts has to be in-service training with wide open range of contents and forms.

Dr. Roman Lavtar je doktoriral aprila 2007 na Fakulteti za družbene vede Univerze v Ljubljani. V svoji več kot dvajsetletni karieri javnega uslužbenca je bil zaposlen na številnih, pretežno vodstvenih in vodilnih delovnih mestih. Kot zunanji ekspert Organizacije združenih narodov je v letih 2004 in 2005 sodeloval v projektu zagotavljanja administrativne usposobljenosti državne uprave za izvedbo zakonodajne reforme v Črni Gori za področje lokalne samouprave, pred tem pa $v$ podobnem projektu PARIM, ki ga je financirala Evropska unija. Predava na strokovnih srečanjih s področja javne uprave in lokalne samouprave, na Upravni akademiji Ministrstva za javno upravo, občasno pa tudi na Fakulteti za družbene vede Univerze v Ljubljani. V letu 2004 mu je senat Fakultete za upravo podelil naziv višjega predavatelja za področje lokalne samouprave, kjer sodeluje pri predmetih Teorija javne uprave in Lokalna samouprava in pri izvedbi programov Svetovalno-izobraževalnega centra fakultete. 


\section{Tacit Knowledge and In-service Training of Civil Servants}

\section{Bibliography}

- Davenport, T. H., Prusak, L. (1997): Information Ecology, Mastering the Information and Knowledge environment, Oxford University Press.

- Dimovski V., Penger S., Žnidaršič J. (2004): Javna uprava kot učeča se organizacija, Uprava, Fakulteta za upravo Univerze v Ljubljani, letnik II, številka 1, julij 2004.

- $\quad$ Drew, S., Coulson-Thomas, C. (1996): Transformation through teamwork: the path to the new organization?, Management decisions 34/1, 1996, MCB University press.

- Fukuyama, F. (2004): State-building, Governance and world order in the 21st century, Cornell University Press, New York.

- Gajduschek, G., György (2000): Evaluation of the Hungarian general civil service training program, Open Society Institute, Discussion papers, not. 16.

- Nonaka, I., Krogh G., Volepel, S. (2006): Organizational knowledge creation theory: evolutionary paths and future advances, Organization studies 27(8), 2006, SAGE Publications, London.

- Nonaka, I. (1994): A dynamic theory of organizational knowledge creation, Organization science, vol. 5, No. 1, 1994 Institute of Management Sciences

- Herzberg, F., Mausner, B. and Snyderman, B.B. (1959): The Motivation to Work, John Wiley, New York.

- Hislop, D. (2005): Knowledge management in organizations, Oxford University Press.

- Mintzberg, H. (1994): Rounding out the Manager's Job, Sloan management Review, Fall 1994.

- Preston, Alistair (1986): Interactions and arrangements in the process of informing, Accounting organizations and society, Vol. 11, No. 6, 1986

- Semler, R. (1989): Managing without managers, Harvard Business Review, September - October 1989.

- Support for improvement in governance and management in Central and Eastern European countries, a joint initiative of the OECD/CCET and EU/PHARE; Budgeting and monitoring of personnel costs; SIGMA PAPER NO. 11, Paris 1997

- $\quad$ Country profiles of civil service training systems, SIGMA papers: No. 12 , OEDC/GD (97)122

- $\quad$ Civil service training in the context of public administration reform, A comparative study of selected countries from Central and Eastern Europe, and the former Soviet Union (1998 to 2003), UNDP, June 2003

- Building blocks and guiding elements for public governance and management in global relations, OEDC, GOV/PGC (2007)REV1, 26-Mar-2007 


\section{POVZETEK}

\section{TACITNO ZNANJE IN STROKOVNO USPOSABLJANJE JAVNIH USLUŽBENCEV}

Avtor $v$ prispevku opozarja na potrebo po spremembi vsebine stalnega strokovnega usposabljanja javnih uslužbencev v luči spoznanj teorije o organizacijskem ustvarjanju znanja. Javni uslužbenci delujejo $v$ negotovem okolju, v pogojih, kjer niso le sposobni reševati problemov, ampak morajo za reševanje teh problemov razvijati novo znanje. Usposobljenost javnih uslužbencev je eden od kazalnikov sposobnosti izvajanja reform, še posebej izražena je njihova sposobnost visoke prenosljivosti znanja. Zato države s sodobnim pogledom na vlogo javne uprave skrbijo za to, da so javni uslužbenci glede tega $v$ dobri kondiciji. Sposobni morajo biti ločevati med podatki, informacijami in znanjem, saj je pogosto proces obrnjen: šele $z$ ustreznim znanjem so sposobni poiskati informacije in kreirati podatke, ki lahko ustvarijo novo znanje. Prispevek se nanaša na razmislek o možnostih uporabe ugotovitev t. i. modela SECI (slov. SEKI) pri usposabljanju javnih uslužbencev. Pri tem modelu gre za razumevanje pretvorbe izraženega (explicit) $\vee$ tiho (tacit) znanje $\vee$ štirih različnih procesih: socializacija - tiho znanje $v$ tiho, eksternalizacija - tiho znanje $v$ izraženo, kombinacija - izraženo znanje $v$ izraženo ter internalizacija - izraženo znanje $v$ tiho. Socializacija je pridobivanje tihega znanja na podlagi opazovanja med mojstrom in vajencem, med starši in otroci, med odraščajočimi vrstniki, vojaki v vojski, itd., pri eksternalizaciji gre za utelešenje in opredmetenje rezultatov dela, pri kombinaciji za iskanje in selekcioniranje podatkov in informacij in pri internalizaciji za ponotranjenje informacij iz knjig in predavanj. Utemeljitelj pojma tacitno znanje je sicer britanski znanstvenik madžarskega rodu Michael Polanyi (1958), SECl model pa sta razvila japonska znanstvenika Nonaka in Takeuchi, ko sta $v$ osemdesetih letih prejšnjega stoletja proučevala prenašanje znanja $v$ japonskih podjetjih.

$\checkmark$ prispevku se med drugim avtor sprašuje, na kakšen način lahko gornja spoznanja uporabimo pri usposabljanju javnih uslužbencev in razmišlja o spremembi pristopa usposabljanju. Pri tem vse prepogosto razmišljamo o obliki, organizaciji in načinu financiranja usposabljanj, namesto o vsebini. Ta v svojem klasičnem razponu prispeva $\mathrm{k}$ ohranjanju institucionalnega spomina, h kontinuiteti, $\mathrm{k}$ poštenosti in zaslugam, vzdrževanju integritete in javnemu zaupanju javnim uslužbencem, $v$ novejšem času še $\mathrm{k}$ nepristranskosti in zakonitosti. Naj gre za organiziranost izobraževanja 
in usposabljanja javnih uslužbencev pred (pre-service) ali po nastopu službe (in-service), glede na ponudbo (supplier funded) ali povpraševanje (buyer funded), centralizirano ali decentralizirano, vedno moramo imeti pred očmi vsebino, ki bo dala resnično usposobljene javne uslužbence. Pri tem je treba vseskozi imeti pred očmi tudi dejstvo, da se javna uprava sooča z različnimi omejitvami, tako kadrovskimi, organizacijskimi kot tudi finančnimi. Eden od mehanizmov za zagotavljanje nepristranskosti, ustrezno raven znanja in preprečitev korupcije in nepotizma je strokovni izpit kot prag za vstop med javne uslužbence. Avtor kljub zavedanju, da ga poznajo mnoge države, da pa vendarle ni univerzalni model, utemeljuje njegove prednosti ter povzema genezo in razvoj preizkusa (proficiency examination) $v$ različnih državah.

Vse do pred nekaj desetletij je veljalo, da novo znanje nastaja le $v$ šolskem sistemu, še posebej na univerzah. Toda post-industrijska revolucija je pokazala podcenjevanje poklicnega in praktičnega znanja ter navrgla spoznanje, da znanje ni v lasti majhne družbene skupine, da je znanje nekaj, kar je utelešeno v praksi, kar izhaja iz konteksta. Koncepta učeče se organizacije (learning organization) in organizacije nabite $z$ znanjem (knowledge intensive organization ali firm) nakazujeta pomen znanja $v$ organizacijah in se ukvarjata z vprašanjem njegovega prenašanja oziroma kroženja $v$ organizaciji. Današnji delavec je vse pogosteje intelektualni delavec (knowledge worker), ki ga označuje intelektualno, kreativno, nerutinsko delo, $v$ katerega je vključena široka uporaba in kreacija znanja. Takšna definicija po mnenju avtorja vsekakor ustreza tudi delu javnih uslužbencev oziroma javni upravi kot organizaciji. Zaradi pomena pretoka znanja $v$ organizaciji se postavlja vprašanje, ali so zaposleni res motivira$\mathrm{ni}$, da prostovoljno širijo znanje, ali je naloga vodstva, da te procese nenehno spodbuja in omogoča. Z vzponom informacijsko komunikacijske tehnologije je namreč ustvarjen napačen vtis, da je znanje mogoče skladiščiti v računalnikih in ga širiti po žicah. Znanje je tudi praksa, znati/delati je neločljivo, znanje je ukoreninjeno $v$ človeku in je družbeno posredovano, kulturno pogojeno in podvrženo dvomu. Zato je model $S E C l$ priročno orodje za pojasnjevanje procesa prenosa znanja $v$ organizaciji, saj znanja ni mogoče odtrgati od ljudi, kot si je to predstavljal Frederick W. Taylor.

Kaj je torej mogoče storiti za pospešitev procesa prenosa znanja? Če gornja načela veljajo za vse organizacije, $v$ katerih so zaposleni ljudje - in avtor ne dvomi, da je tako - potem je treba uporabiti enake ukrepe za večjo usposobljenost javnih uslužbencev tudi $v$ javni upravi. In to na 
način, da ne dodajamo programom usposabljanja vedno novih in novih vsebin, pač pa da spremenimo načela usposabljanja javnih uslužbencev in temu podredimo vsebino. To še posebej velja za usposabljanje vodstvenih javnih uslužbencev. Ti so po Mintzbergu tisti, ki morajo delo organizirati tako, da bo prenos znanja mogoč, njihova enako pomembna naloga pa je, da so interpreti informacij in znanja, ki kroži po organizaciji. Poleg tega je treba $v$ organizaciji vzpostaviti motivirajoče ozračje. Plača je le higienik (Herzberg) resnična motivacija za zaposlene so dejavniki kot pohvala za doseženo, priznavanje vloge zaposlenih za razvoj organizacije, odgovornost in promocija.

Za razumevanje spremembe vsebine usposabljanj javnih uslužbencev je treba poudariti še dva organizacijska ukrepa, ki prispevata k širjenju znanja $v$ organizaciji. Prvi je odstop od Taylorjeve segmentacije in specializacije dela (Semler), druga pa vključitev zaposlenih $v$ proces sprejemanja odločitev skozi timsko delo (team work), ki ga je po Drewu in Coulsonu treba razlikovati od skupinskega dela oziroma delovnih skupin (group work). Timsko delo uspešno lomi pregrade za učinkovito komunikacijo in sodelovanje med zaposlenimi, poveča hitrost odzivanja, dviguje nivo pripadnosti, ustvarja bolj na odjemalce usmerjeno kulturo in povečuje organizacijsko prilagodljivost in gibčnost. Pogoste ovire za timsko delo so pomanjkanje podpore vodstva, pomanjkanje jasne vizije in ciljev organizacije, odsotnost nagrajevanja skupinskih dosežkov, neustrezno usposabljanje, premajhno dopuščanje avtonomije pri sprejemanju odločitev, pomanjkanje veščin projektnega vodenja, vpletanje politike, pomanjkanje timskega duha in nepotrpežljivost vodstva.

Dodatna ovira za širjenje znanja $v$ organizaciji so tudi ovire pri širjenju informacij vodstvenih delavcev. Preston poudarja, da so poti za medsebojno informiranje tako formalne kot neformalne in da posebej slednje ne gre zanemarjati. Obe vrsti imata pomemben vpliv na izvajanje nalog vodstvenih delavcev. Potreba 'vedeti' mora biti vtkana $v$ vsakodnevno obnašanje in delovanje zaposlenih in vodij, njihova medsebojna interakcija mora biti vir pomena in skupnih aktivnosti, ki omogoča opredeljevanje aktualnih okoliščin in načrtovanje reakcij. Da bi bili vključeni v informiranje, morajo biti vodstveni javni uslužbenci prepoznani kot zanesljiv vir informacij. Neformalne poti informiranja nastajajo prav zaradi pomanjkanja in omejitev formalnih virov. Uporaba informacijsko komunikacijskih orodij nam daje napačen vtis, da smo informirani. 


\section{Roman Lavtar \\ Tacit Knowledge and In-service Training of Civil Servants}

Avtor v zaključku poudari, da je splošni državni izpit za javne uslužbence zgolj vrh ledene gore usposabljanja javnih uslužbencev. Z njim se začne potovanje po vodah javne uprave. Toda kar šteje, je usposabljanje po vstopu zaposlenih $v$ uslužbensko razmerje. Zdi se, da nismo izkoristili vseh možnosti, ki nam jih dajejo sodobna spoznanja o širjenju znanja $v$ organizacijah. Na srečo smo razvili zavedanje o pomembnosti trajnega reformiranja javnega sektorja skupaj s sistemom usposabljanja javnih uslužbencev. Rdeča nit naših naporov mora biti usposabljanje s širokim razponom tako oblik kot vsebin. 